\title{
Experimental model of pulmonary carcinogenesis in Wistar rats ${ }^{1}$
}

\author{
Modelo experimental de carcinogênese pulmonar em ratos Wistar
}

\author{
Baldomero Antonio Kato da Silva ${ }^{2}$, Iandara Schettert Silva ${ }^{3}$, Daniel Martins Pereira ${ }^{4}$, Ricardo Dutra Aydos ${ }^{5}$, Paulo de \\ Tarso Camillo de Carvalho ${ }^{6}$, Gilberto Gonçalves Facco ${ }^{7}$ \\ 1. Postgraduate Program in Heath Sciences in the Central West Region - Federal University of Brasília (UnB) and Federal University of \\ Mato Grosso do Sul (UFMS), Campo Grande, Brasil. \\ 2. Fellow PhD degree, Health and Development Post Graduation from UFMS; Master in Health Sciences Post-Graduation from UnB/UFMS; \\ Associate Professor at University for Development of the State and Pantanal Region - UNIDERP, Brazil. \\ 3. PhD, Associate Professor at UNIDERP, Brazil. \\ 4. Fellow Master Degree in Health and Development Post Graduation from UFMS; Associate Professor at UNIDERP, Brazil. \\ 5. PhD, Associate Professor at Clinical Surgery/UFMS, Brazil. \\ 6. PhD, Associate Professor at UNIDERP, Brazil. \\ 7. Master in Animal Pathology, UNESP; Associate Professor at UNIDERP.
}

\begin{abstract}
Purpose: To elaborate an experimental model of pulmonary carcinogenesis in Wistar rats. Methods: Male Rattus norvegicus albinus, Wistar lineage was carried through an intra-pulmonary instillation of the Benzo[a]pyrene (B[a]P) dilution in alcohol 70\%, a polycyclic aromatic hydrocarbon widely known by its power of tumoral induction. Three experimental groups had been formed with 08 animals each: Control Group (Alcohol 70\%); B[a]P Group 10 mg/kg; e B[a]P Group 20mg/ $\mathrm{kg}$, submitted to euthanasia 08, 10, 12 and 14 weeks after the experimental procedure. The pulmonary sections had been colored by hematoxilin-eosin (HE) and submitted to the morphometrical analysis to describe the tissue alterations. Results: The presence of diffuse inflammatory alterations was observed in all groups, however, at the analysis of the pulmonary tissue of the experimental groups, it had been observed hyperplasic alterations (BALT hyperplasia), and in one of the animals of the experimental group 20mg/kg (12 weeks), it was noticed the presence of cellular epithelial tracheal pleomorphism, suggesting the adenocarcinoma formation in situ. Conclusion: The main secondary alterations to the intra-pulmonary instillation of B[a]P in Wistar rats were: cellular proliferation, inflammatory alterations of several degrees and nodular lymphoid hyperplasias. The association of an activator agent of the pulmonary metabolic reply is necessary to establish the ideal reply-dose to the development of the lung cancer.
\end{abstract}

Key words: Carcinogenesis. Lung Cancer. Benzo[a]pyrene. Neoplasms. Experimental model.

\section{RESUMO}

Objetivo: Elaborar um modelo experimental de carcinogênese pulmonar em ratos wistar. Métodos: Rattus norvegicus albinus, linhagem Wistar foram submetidos a instilação intra-pulmonar da diluição em álcool 70\% de Benzo[a]pireno (B[a]P), um hidrocarboneto aromático policíclico amplamente conhecido por seu poder de indução tumoral. Foram formados três grupos experimentais com 08 animais cada: Grupo Controle (álcool 70\%); Grupo B[a]P 10 mg/kg; e Grupo B[a]P 20mg/ kg, submetidos a eutanásia 08, 10, 12 e 14 semanas após o procedimento experimental. As secções pulmonares foram coradas por HE e submetidas a análise morfométrica para descrição das alterações teciduais. Resultados: em todos os grupos observou-se a presença de alterações inflamatórias difusas, porém na análise do tecido pulmonar dos grupos experimentais, observou-se alterações hiperplásicas (hiperplasia de BALT), e em um dos animais do grupo experimental 20mg/kg (12 semanas) notou-se a presença de pleomorfismo celular epitelial traqueal, sugerindo a formação de adenocarcinoma in situ. Conclusão: as principais alterações secundárias à instilação intra-pulmonar de B[a]P em ratos Wistar foram: proliferação celular, alterações inflamatórias de diversos graus e hiperplasias nodulares linfóides. A associação de um agente ativador da resposta metabólica pulmonar pode ser necessária para estabelecimento da dose-resposta ideal ao desenvolvimento do câncer de pulmão.

Descritores: Carcinogênese. Câncer de Pulmão. Benzo[a]pireno. Neoplasias. Modelo experimental. 


\section{Introduction}

Lung cancer remains the commonest cause of cancer death in both man and women in the development world, and is one of the most important diseases in respiratory medicine ${ }^{1}$. Although cancer has often been regarded principally as a problem of the developed world, of the 10 million new cancer cases each year, 5.5 million of them are in developing countries. Every year, there are more than 6 million cancer deaths, accounting for $12 \%$ of all deaths in the world. Over the next 20 years, the number of cancer deaths annually will rise to some 10 million $^{2}$. Cancer arises principally as a consequence of exposure of individuals to carcinogenic agents in what they inhale or eat and drink, or through exposures at their work or elsewhere. Rather than inherited genetic characteristics, other factors play the major roles in the etiology of cancer. These include personal habits such as tobacco use and dietary patterns, occupational exposure to carcinogens, and biological factors such as viral hepatitis B infection and human papillomavirus infection ${ }^{2}$. Environmental air pollution and smoking habits are the main sources of inhalation exposure to carcinogenic agents such as polycyclic aromatic hydrocarbons (PAH). PAHs are currently recognized as one of major classes of environmental carcinogenic pollutants ${ }^{3}$. Benzo[a]pyrene $(\mathrm{B}[\mathrm{a}] \mathrm{P})$ is a member of PAH family, and is often used as a model compound for PAH toxicity studies and has been shown to be a potent lung carcinogen in animal models of lung cancer. The selective carcinogenesis of the lung following exposure to $\mathrm{B}[\mathrm{a}] \mathrm{P}$ may be a consequence of many biochemical factors, including those that affect absorption, metabolism, and DNA repair ${ }^{4}$. B[a]P has been used as a prototype carcinogenic polycyclic aromatic hydrocarbons since its isolation from coal tar in the 1930's. It produce a wide range of toxicities, including carcinogenicity in experimental animals, and acute inhalation induces squamous cell papillomas and carcinomas in the trachea ${ }^{5}$. Although most cases of lung cancer could be prevented, the treatment of lung cancer is often disappointing. In the study of cancer, the efficacy of new treatment ideas in various cell lines can be investigated $^{6}$. There are few animal models of human lung cancer, and a animal model of tumor permits the evaluation in vivo of new chemotherapic drugs in the treatment of bronchogenic lung cancer ${ }^{7}$. Animal models act as a bridge between in vitro studies in the laboratory and studies in humans. As such, they have had a major impact on the investigation of many medicals conditions. The mouse provides the best choice for an animal model because the mouse genome has been extensively studied and sequenced and close similarities exist with the human genome $^{8}$. In parallel with studies in humans, these animal models can be used to evaluate methods of possible chemoprevention and early detection ${ }^{9}$. Spontaneous lung tumors in mice are similar in morphology, histopathology, and molecular characteristics to human adenocarcinomas. Mouse models for lung cancer can thus serve as a valuable tool not only for understanding the basic lung tumor biology bus also for the development and validation for new tumor intervention strategies ${ }^{10}$. The aim of this study is to elaborate an experimental model of pulmonary carcinogenesis in Wistar rats, and to establish the dose of benzopyrene and necessary time of application to the induction of cellular alterations compatible with pulmonary cancer in Wistar rats.

\section{Methods}

Male Rattus norvegicus albinus, Wistar lineage 08 to 12 weeks of age were obtained from UFMS central bioterio. Animals were housed four per cage on hardwood chip bedding and were given food and purified tap water ad libitum. Rats were randomized into treatment groups and were quarantined for 2 weeks prior to treatment, during which time they were acclimatized to 12-h light-dark cicles. B[a]P was suspended in alcohol $70 \%$ to obtain 10 and $20 \mathrm{mg} / \mathrm{ml}$ concentrations. Rats were anesthetized with a mixture of ketamine and xilazine, positioned in supine and a thoracocentesis with a $13 \mathrm{X} 4,5$ needle was realized in left lung. Rats (eight per group) were given a single intrapulmonary instillation of $\mathrm{B}[\mathrm{a}] \mathrm{P}$ at doses of 10 and $20 \mathrm{mg} / \mathrm{kg}$ using a 1 -ml sterile syringe that was attached to the needle. The animals (two by two) were killed 08, 10, 12 and 14 weeks after the intrapulmonary instillation. A group of 08 rats (control) were also instilled with alcohol 70\%. Until their sacrifice, all animals were maintained four per cage under controlled ambient conditions and with free access to food and water. Rats were killed by intraperithoneal infusion of lethal dose of sodium penthobarbital. The pulmonary sections had been colored by hematoxilin-eosin (HE) and submitted to the morphological analysis to describe the tissue alterations. All experiments respected the international rules for animal experimentation.

\section{Results}

The findings of the hystopathological analysis observed in the experimental groups at the sections colored by $\mathrm{HE}$ are described in the figures 01, 02, 03 and 04. Inflammatory alterations had been observed in all the animals of the analyzed groups, in three animals of the experimental group 10mg (08,10 and 14 weeks) and three of the experimental group 20mg (08, 12 and 14 weeks) had been observed lymphoid nodular hyperplasias (BALT, bronchial associated lymphoid tissue). Injury suggesting tumoral induction was observed at only one animal (experimental group 20mg, 12 weeks), which presented a pleomorphism suggesting an adenocarcinoma in situ in the tracheal epithelium. 


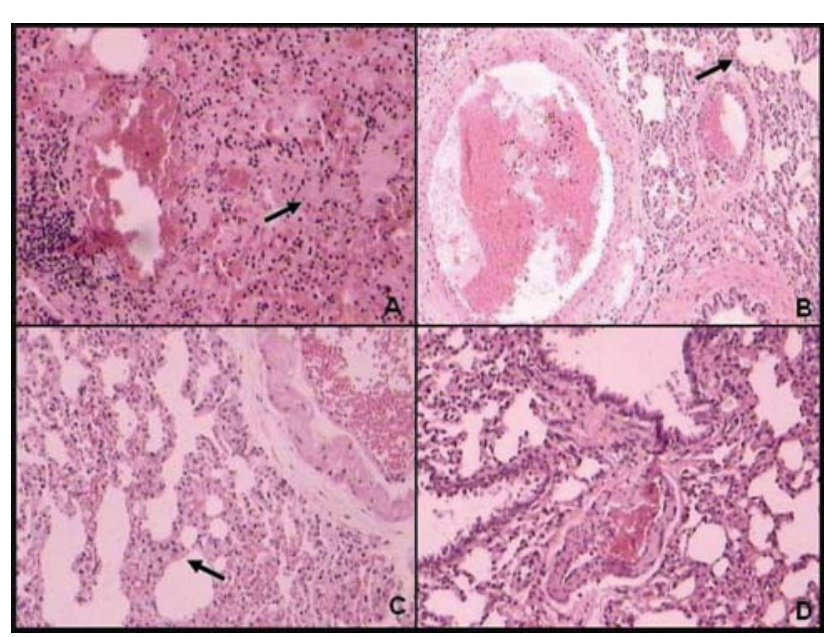

FIGURE 1 - Microscopy of the pulmonary sections of the Control Group. A) 08 weeks. Diffuse chronic inflammatory process is noticed, the arrow shows alveolar acinus with the presence of protean exsudate. B) 10 weeks. Diffuse chronic inflammatory process. The arrow indicates an area of pulmonary emphysema. C) 12 weeks. Diffuse chronic inflammatory process. The arrow indicates thickness of the alveolar wall after the inflammation. D) 14 weeks. Diffuse chronic inflammatory process, with emphysema areas and thickness of the alveolar walls. (HE, 100X)

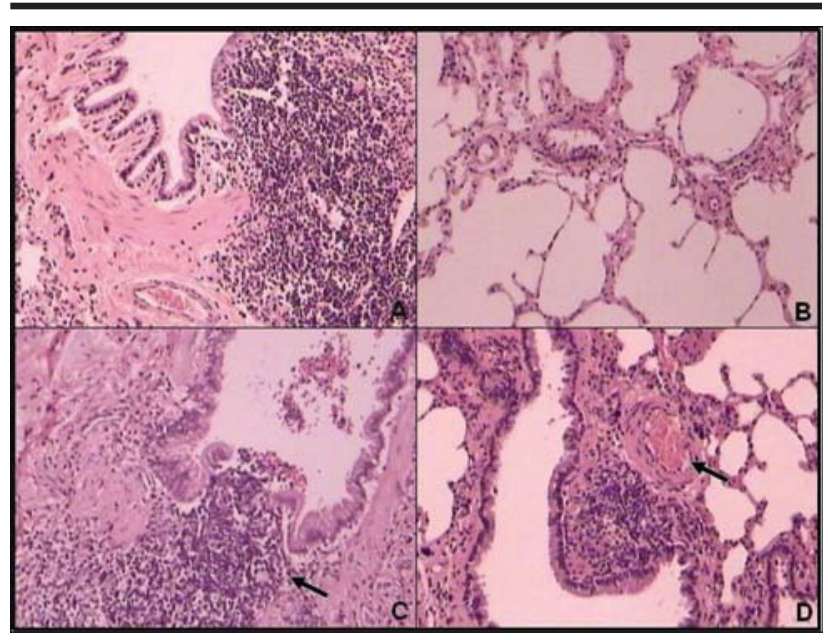

FIGURE 3 - Microscopy of the pulmonary sections of the group 20mg/kg. A) 08 weeks. Lymphoid nodular hyperplasia (BALT). B) 10 weeks. Pulmonary emphysema with focal inflammation areas. C) 12 weeks. Diffuse chronic inflammatory process. The arrow shows lymphoid nodular hyperplasia (BALT). D) 14 weeks. Diffuse chronic inflammatory process, with emphysema areas and thickness of the alveolar walls. Lymphoid nodular hyperplasia (BALT). Congested blood vase (arrow). (HE, 100X)

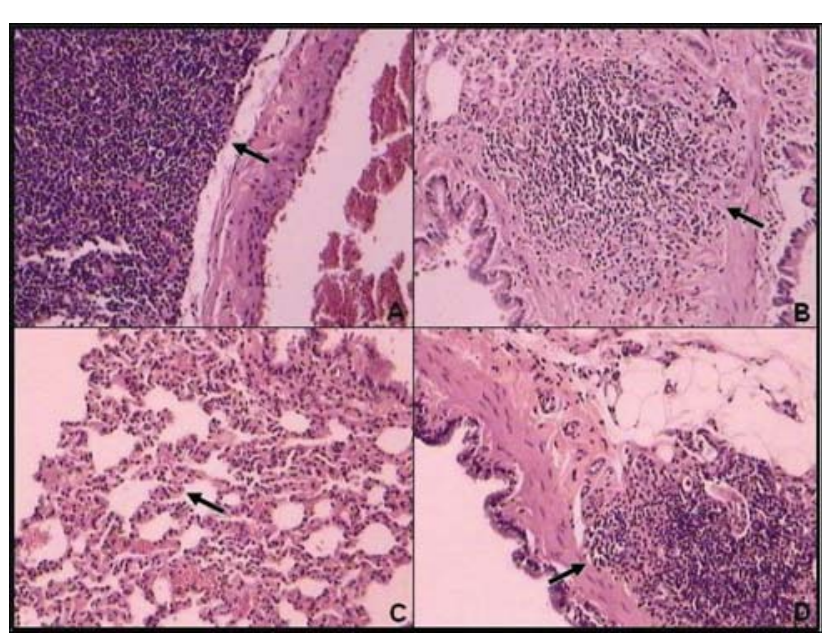

FIGURE 2 - Microscopy of the pulmonary sections of the group $10 \mathrm{mg} / \mathrm{kg}$. A) 08 weeks. The arrow shows lymphoid nodular hyperplasia (BALT hyperplasia). B) 10 weeks. Diffuse chronic inflammatory process. The arrow indicates lymphoid nodular hyperplasia (BALT). C) 12 weeks. Focal chronic inflammatory processes. The arrow indicates thickness of the alveolar wall. D) 14 weeks. Lymphoid nodular hyperplasia (BALT). (HE, 100X)

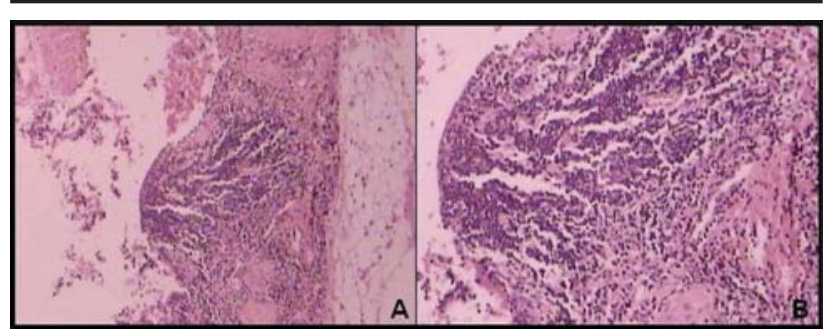

FIGURE 4 - Pulmonary section microscopy. Group 20mg/ kg, 12 weeks. Pleomorphism compatible with adenocarcinoma in situ. (HE,: 50X; B: 100X) 


\section{Discussion}

In this study, it was opted to use rats at the development of the experimental model. According to Dawkins and Stockley (2001), the rats represent the best option for animal models of illness, because its genoma has been extensively studied and its sequence shows similarities with the human genoma $^{8}$. Meuwissen and Berns (2005) affirm that the spontaneous lung tumors in rats are similar in morphology, hystopathology and molecular characteristics of the human adenocarcinomas. Models of lung cancer in rats can serve, therefore, as a valuable tool not only to the understanding of the biological bases of these tumors, but also to the development and validation of new interventions and strategies to the cancer treatment, as well as the identification of markers for the early diagnosis ${ }^{10}$. It was opted in this study the injection of the diluted $\mathrm{B}[\mathrm{a}] \mathrm{P}$ by thoracocentesis, when Garçon et al. (2001) offers the tracheal instillation as a study option on the PAH effects at the pulmonary tissue ${ }^{11}$. Similar methodology to this study was used by Harrigan et al. (2004). The authors tell that, in despite of the injection with thoracocentesis be apparently the most efficient method of cancer induction, the low metabolic activation found in the pulmonary tissue can disable the action of the $\mathrm{B}[\mathrm{a}] \mathrm{P}$ while carcinogenic ${ }^{4}$. Gerde et al. (2001) emphasize the paper of the tissular metabolism in the elimination of the $\mathrm{PAH}$, telling in its study that only $23 \%$ of the instilled dose in the tracheal epithelium is effectively absorbed. Studies using repeated intra-tracheal administrations of PAH had been incapable to get the reply-dose necessary to the induction of lung cancer with accuracy ${ }^{12}$. The induction method and the dose used are related as a greatly influent component at the pulmonary carcinogenesis ${ }^{10}$. The analysis of the available literature, references had not been found on the accurate reply-dose of $\mathrm{B}[\mathrm{a}] \mathrm{P}$ enough to the induction of pulmonary carcinogenesis, however it observes that at the studies which outcomes related the instillation of $\mathrm{B}[\mathrm{a}] \mathrm{P}$ to tissular alterations, molecular or genetic in the lungs, the doses had varied between $10 \mathrm{mg} / \mathrm{kg}$ and $50 \mathrm{mg} / \mathrm{kg}^{4,11,12}$. It was used coloration by $\mathrm{HE}$ for the hystopathological analysis. According to Franklin (2000) the analysis of the microscopical findings of the tumoral sections colored by $\mathrm{HE}$ are still the most commonly method used to the classification of the lung cancer ${ }^{13}$. In only one of the studied animals, the neoplasia alterations had been found (pleomorphism suggesting adenocarcinoma in situ), observed specifically in the tracheal epithelium. Rubin (2001) relates that almost the totality of the $\mathrm{PAH}$ are completely carcinogenic, not being necessary other interventions at the experimental cancer induction, however, emphasizes several times in his study that such property is conditioned to the presence of epithelial tissue ${ }^{14}$. Non-observation of the alterations compatible with lung cancer (the exception of an animal of the experimental group $20 \mathrm{mg} / \mathrm{kg}$ ), can be explained by the absence of metabolic activation. Garçon et al. (2001) suggest that the exposition to an associated oxidant agent to the carcinogenic ones, induces greater release of pro-inflammatory mediators, contributing to the process of carcinogenesis activation ${ }^{11}$. In three animals of the experimental groups, the presence of BALT hyperplasia was observed. Although normally constitute inespecific injuries, Miranda et al., (2003) consider the hyperplasical injury as one of the alterations associated to the development of the lung cancer ${ }^{15}$. As other lymphomas, it is believed that BALT hyperplasia originates from a lymphoid hyperplasia for abnormal neoplasic selection, frequently associated to the antigenic interaction with environmental pollutants ${ }^{16,17}$. All studied animals (including the control group) had presented some degree of inflammatory process. The inflammation has been associated to the development of diverse pulmonary illnesses, including the cancer. Especially in experiments using rats, the pulmonary inflammatory process is frequent and directly related to the incidence of lung cancer ${ }^{3,12}$. In this study, a simple instillation of the dilution solution was carried through, probably causing the acute inflammatory process. Miranda et al., (2003) relate that the frequent genetic mutations secondary the tissular aggression occur continuously and are repaired by the cellular defense mechanism, that controls the growth, the latency and cellular apoptosis, emphasizing the need of the continuity of the inflammatory process at the carcinogenesis induction ${ }^{15}$. It was observed in this study that several degrees of inflammatory replies could be observed in all the analyzed moments (8, 10, 12 and 14 weeks after the instillation). Lu, Ouyang and Huang (2006), emphasize the importance of the continuous aggression at the cancer induction, affirming that in many cases the acute inflammation can contribute to the regression of the carcinogenesis ${ }^{18}$. To establish the ideal reply-dose to the development of the lung cancer, it becomes necessary the association to an activator agent of the pulmonary metabolic reply, which without it, the reaction to the $\mathrm{B}[\mathrm{a}] \mathrm{P}$ probably will be not enough to start the induction process of pulmonary neoplasias by mutagenesis.

\section{Conclusion}

The intra-pulmonary injection of Benzopyrene is an easy method of accomplishment, but the carcinogenic injury's observation occurred in only one animal (20mg/kg, 12 weeks). BALT lymphoid nodular hyperplasias (considered for some authors as possible pre-carcinogenic injury) occurred in six animals, suggesting that the intra-pulmonary injection can be an adequate model when used largest doses and observation periods. It had been observed in this study significant differences to the used doses at the cellular proliferation after the intra-pulmonary injection of B[a]P. Such differences had revealed to be time and dose-dependents. The main secondary alterations to the intra-pulmonary instillation of $\mathrm{B}[\mathrm{a}] \mathrm{P}$ in Wistar rats observed in this study had been: cellular proliferation, inflammatory alterations of several degrees and lymphoid nodular hyperplasias. 


\section{References}

1. Spiro S, Porter JC. Lung Cancer - Where are we today? Am J Respir Crit Care Med. 2002; 166: 1166-96.

2. World Health Organization. Policies and managerial guideliness for national câncer control programs. Rev Panam Salud Publica. 2002; 12(5): 36

3. Agen B, Maas LM, Zwingmann IH, Schooten FJV, Kleinjans JCS. B[a]P adduct formation and induction of human epithelial lung cell transformation. Environ Mol Mutagen. 2001; 30: 287-92.

4. Harrigan JA, Vezina CM, McGarrigle BP, Ersing N, Box HC, Maccubbin AE, Olson JR. DNA adduct formation in precision-cut rat liver and lung slices exposed to benzo[a]pyrene. Toxicol Sci. 2003; 77: 307-14.

5. Silva BAK, Silva IS, Pereira DM, Aydos RD, Carvalho PTC. Usefulness of argyrophilic nucleolar organizer regions in detection of lung cells alterations after benzo[a]pyrene instillation. Acta Cir Bras. 2006;21(Suppl 4):36-9.

6. Silva LFG, Soares FSD, Anselmo JNN, Fé DMM, Cavalcante JLBG, Moraes MO, Vasconcelos PRL. Modelo de tumor experimental em rim de ratos. Acta Cir Bras. 2002;17(1):62-6.

7. Rom WN, Hay JG, Lee TC, Jiang Y, Tchou-Wong KM. Molecular and genetic aspects of lung cancer. Am J Res Crit Care Med. 2000; 161:1355-67.

8. Dawkins PA, Stockley RA. Animal models of chronic obstructive pulmonary disease. Thorax. 2001; 56: 972-7.

9. Benfield JR, Hammond WG. Bronchial and pulmonary carcinogenesis at focal sites in dogs and hamsters. Cancer Res.1992; 52: S2687-93.
10. Meuwissen R, Berns A. Mouse models for human lung cancer. Genes \& Dev. 2005; 19: 643-64.

11. Garçon G, Gosset P, Garry S, Marez T, Hannothiaux $\mathrm{MH}$, Shirali P. Pulmonary induction of proinflammatory mediators following the rat exposure to benzo(a)pyrene-coated onto $\mathrm{Fe}_{2} \mathrm{O}_{2}$ particles. Toxicol Lett. 2001; 121: 107-17.

12. Gerde P, Muggenburg BA, Lundborg M, Dahl AR. The rapid alveolar absorption of diesel soot-absorbed benzo[a]pyrene: bioavailability, metabolism and dosimetry of an inhaled particle-borne carcinogen. Carcinogenesis. 2001; 22(5): 741-9.

13. Franklin WA. Diagnosis of lung cancer - pathology of invasive and preinvasive neoplasia. Chest. 2000; 117: S80-9.

14. Rubin H. Synergistic mechanisms in carcinogenesis by polycyclic aromatic hydrocarbons and by tobacco smoke: a bio-historical perspective with updates. Carcinogenesis. 2001; 22(12): 1903-30.

15. Miranda DGN, Jamnik S, Santoro IL, Uehara C. Avaliação do escarro induzido no diagnóstico do carcinoma brônquico. Rev Bras Cancerol. 2003; 49(2): 91-8.

16. Salinas J, Leiva IR, González SB. Proliferaciones linforreticulares del pulmón. Rev Chil Enf Respir. 2006; 22: 108-16.

17. Porter DW, Hubbs AF, Mercer R, Robinson VA, Ramsey $\mathrm{D}$, McLaurin $\mathrm{J}$ et al. Progression of lung inflammation and damage in rats after cessation of silica inhalation. Toxicol Sci. 2004; 79: 370-80.

18. Lu H, Ouyang W, Huang C. Inflammation, a key event in câncer development. Mol Cancer Res. 2006; 4(4): 1-13.

\section{Correspondence:}

Baldomero Antonio Kato da Silva

Beirute No. 289, Jardim Palmira

CEP 79112-150

Campo Grande, MS, Brazil

e-mail: ftbaldock@uol.com.br
Interest conflict: none

Financing source: none 